\title{
INFLUENCE OF SODIUM BICARBONATE SUPPLEMENTATION ON NUTRIENTS DIGESTIBILITY, MILK PRODUCTION, RUMEN FERMENTATION AND SOME BLOOD PARAMETERS IN SHEEP
}

\author{
M.M. Farghaly ${ }^{1}$, E. H. Hassan ${ }^{2}$ and S. G. Abdo ${ }^{2}$ \\ 1- Animal Production Department, Faculty of Agriculture, Assiut University, Egypt, 2- Animal Production \\ Department, Faculty of Agriculture, Al-Azhar University Assiut, Egypt
}

Received: 17/1/2019 Accepted: 28/2/2019

\section{SUMMARY}

This study was conducted to evaluate the effect of supplementing the diet of ewes or rams with sodium bicarbonate $\left(\mathrm{NaHCO}_{3}\right)$ as buffers at two levels on feed intake, milk yield, milk composition, nutrient digestibility, rumen fermentation and some blood metabolites. Twenty seven healthy mature local ewes were randomly assigned into three similar groups ( 9 ewes each). Three dig estibility trials were also carried out using twelve local rams randomly assigned into three groups (4 rams/ trial). Each trial lasted for three weeks, the first two weeks were considered as a preliminary period followed by one week collection period. Groups of 9 ewes and 4 rams were the control group fed the basal diet without $\mathrm{NaHCO}_{3}$ supplement and treated groups were fed either 1.5 (T1) or 3\% (T2) sodium bicarbonate mixed with the concentrate mixture. All animals were fed $70 \%$ of their requirements as concentrate mixture while, wheat straw was given ad libitum as roughage. Dietary supplementation of $\mathrm{NaHCO}_{3}(1.5$ or $3 \%)$ increased $(P<0.05)$ dry matter intake $(D M I)$ of roughage and total dry matter intake. Sodium bicarbonate supplement increased $(P<0.05)$ milk yield. The milk fat $(\%)$ was improved $(P<0.05)$ in ewes supplemented 3\% of $\mathrm{NaHCO}_{3}$ compared to other groups. Dietary supplement of sodium bicarbonate either 1.5 or $3 \%$ increased $(P<0.05)$ serum $p H$ and cholesterol. The organic matter, crude protein and crude fiber digestibility coefficients were improved $(P<0.05)$ for rams supplemented with 1.5 and $3 \%$ sodium bicarbonate compared with the control group. Supplementation of sodium bicarbonate to rams rations increased $(P<0.05)$ ruminal $p H$, concentrations of total VFAs and total protozoa count as compared with the control diet. However, rumen ammonia nitrogen was not affected. In conclusion, dietary sodium bicarbonate in particular $3 \%$ of concentrate mixture improves dry matter intake, milk yield, milk fat (\%), nutrients digestibility and fermentation patterns in sheep.

Keywords: sodium bicarbonate, ewes, sheep, milk yield, milk composition, nutrient digestibility, rumen fermentation, blood parameters

\section{INTRODUCTION}

The ewes postnatal in early lactation require high energy levels for milk production, thus large amounts of concentrate ingredients in ewes rations are needed. High-energy, low-fiber rations are rapidly fermented to volatile fatty acids in the rumen resulting in a decrease of $\mathrm{pH}$ throughout the gastrointestinal tract (Linda et al., (1985). High concentrate diets decrease rumen $\mathrm{pH}$ and fiber digestibility (Santra et al., 2003), thereby reducing the buffering capacity of the rumen contents and increasing the risk of ruminal acidosis (Kawas et al., 2007). High-energy, low-fiber rations increased acid levels in the rumen, which could be detrimental to the rumen papillae. Ruminal papillae damage results in poor absorption of feed nutrients in the rumen which may reduce feed intake, and result in a decrease of milk yield and its fat content (Donald et al., 1984). To avoid such incidence, several nutritional therapies have been tried, including the use of dietary buffers. Sodium bicarbonate $\left(\mathrm{NaHCO}_{3}\right)$ is a natural buffer (Erdman, 1988), and one of the dietary buffers commonly used to prevent ruminal $\mathrm{pH}$ reduction and enhance ruminal fermentation of low roughage diets (Le Ruyet and Tucker, 1992; Russell and Chow, 1993). The NRC (1989) suggested that $\mathrm{NaHCO}_{3}$ should be added at a level of Issued by The Egyptian Society of Animal Production
$1.2-1.6 \%$ in the concentrate mixture of dairy cattle rations to control ruminal $\mathrm{pH}$. Dietary buffer supplementation has variable effects on animals, which may be attributed to concentrate to forage ratio, level of intake, types and levels of added mineral buffers (Santra et al., 2003).

The addition of sodium bicarbonate has variable effects on lamb's performance (Sen et al., 2006), including no effects (Gonzalez et al., 2008) or negative effects (Bodaset al., 2009).Also, $\mathrm{NaHCO}_{3}$ has a buffer activity, increases dry matter intake and stabilizes rumen $\mathrm{pH}$ (Hutjens, 1991). Moreover, there are only few studies on the effects of $\mathrm{NaHCO}_{3}$ supplementation in small ruminants, particularly in lactating ewes fed a high concentrate diet.

Therefore, the aim of the present study was to investigate the effect of different levels of dietary sodium bicarbonate supplementation in high concentrate-fed ewes and rams on feed intake, rumen fermentation, milk production along with some blood metabolites.

\section{MATERIALS AND METHODS}

This experiment was carried out at the Animal Production Research Farm, Faculty of Agriculture, Al-Azhar University, Assiut branch and Animal 
Production Department, Faculty of Agriculture, Assiut University.

\section{Animals, diets and management:}

Twenty seven healthy mature local ewes (1.5- 2 years old with an average body weight $40 \pm 2 \mathrm{~kg}$ ) were divided into three groups (nine ewes each), according to their average live body weight. The average initial weights were similar in all groups. The control group was fed a basal diet consisting of roughage and concentrates mixture, but the two treated groups were fed the basal diet supplemented with either $1.5 \%$ (T1) or 3\% (T2) of sodium bicarbonate to the concentrate mixture. Seventy $\%$ of the requirement was covered by a concentrate mixture, while wheat straw was given ad libitum as a roughage.The quantity of concentrate mixture was adjusted every two weeks according to the change in body weight (NRC, 1985).Daily feed intake was recorded and representative samples from feed were taken for chemical analysis according to the procedures of Association of Official Analytical Chemists(AOAC, 2005).Fresh water was available ad libitum. The ewes were individually housed in pens. The ingredients and chemical composition of the concentrate mixture and the wheat straw are shown in Table (1).

\section{Milk yield measurement:}

Daily milk yield (g/day) for each ewe was recorded from the $15^{\text {th }}$ day post lambing till weaning at about three months lactating period using lamb's suckling technique as described by Ashmawy (1980).This technique was used two times with each ewe per week. Milk samples were analyzed for protein, fat, solid not fat, total solids and lactose using the methods devised by (AOAC, 2005).

Table 1. Formulation of concentrate feed mixture and chemical composition of concentrate mixture and wheat straw

\begin{tabular}{lcc}
\hline Items & Concentrate mixture & Wheat straw \\
\hline Ingredients composition (\%) & 44 & - \\
Corn & 30 & - \\
Wheat bran & 22 & - \\
Corticated cotton seed meal & 2 & - \\
Limestone & 1 & - \\
Salt & 1 & - \\
Vitamin and mineral (Premix ${ }^{*}$ ) & & 90.63 \\
Chemical composition, \% on Dry matter basis & 96.06 & 88.20 \\
Dry matter (DM) & 91.77 & 3.00 \\
Organic matter (OM) & 14.20 & 39.33 \\
Crude protein (CP) & 11.70 & 01.73 \\
Crude fiber (CF) & 2.75 & 44.13 \\
Ether extract (EE) & 63.12 & 11.80 \\
Nitrogen free extract (NFE) & 8.23 & \\
Ash & & \\
\hline Minerals and vitamins premix composition, containing 18 \% calcium (Calcium carbonate), $6 \%$ phosphorus (Mono calcium \\
phosphate), 6.5\% sodium (sodium chloride), 3\% magnesium (Magnesium oxide), 450,000 IU Vitamin A/kg, $80.000 \mathrm{IU}$ \\
vitamin D3 /kg, 2.125 mg vitamin E/kg. &
\end{tabular}

\section{Blood sampling:}

Blood samples were collected by jugular veinpuncture at the end of the experiment $6 \mathrm{hrs}$. after the morning feeding. Blood samples were then centrifuged at $3000 \mathrm{rpm}$ for $20 \mathrm{~min}$ for harvesting serum then stored at $-20^{\circ} \mathrm{C}$ till analyzed for blood parameters. Blood constants (cholesterol, pH, glucose, total protein, AST and ALT were analyzed by spectrophotometer (Unico, USA) using commercial test kits (Spinreact, Spain).

\section{Digestibility trial:}

The digestibility trials were carried out using twelve local rams (two years old and about $52 \pm 1.25$ $\mathrm{kg}$ body weight). Each trial lasted for 3 weeks, the first 2 weeks were considered as a preliminary period followed by one week collection period. Animals were randomly distributed into three experimental groups, each with four rams. The animals in group one were considered as a control, which was fed a basal diet consisting of concentrate mixture and wheat straw. The second group (T1) and the third one (T2) received the same basal diet with supplying the concentrate mixture with $1.5 \%$ and $3 \%$ of sodium bicarbonate, respectively.

\section{Chemical analysis and digestion coefficients measurements:}

The diet samples were taken daily during the collection period. At the end of the collection period, samples were mixed and grounded through $1 \mathrm{~mm}$. screen for chemical analysis. Feces were collected daily and $10 \%$ of its weight were taken and dried at $60-70{ }^{\circ} \mathrm{C}$ for $24 \mathrm{hrs}$. The fecal samples from each animal were composited and grounded through a $1 \mathrm{~mm}$ mill screen for subsequent chemical analysis. The chemical analysis of feeds, residuals and feces were carried out using the procedures of Association of the Official Analytical Chemists (AOAC, 2005).The apparent digestion coefficients of nutrients 
were calculated by expressing the difference between the content of nutrients in both consumed feed and feces as a percentage of its intake.

\section{Rumen liquor parameters:}

Rumen content samples were collected once from each ram, using a stomach tube, at the end of the digestibility trial. Samples were taken $4 \mathrm{hrs}$. after the morning feeding. Rumen liquor samples were divided into two parts, the first part was filtered through one layer of cheese-cloth, which was used to measure the protozoa count. The total protozoa count was conducted according to Abou El-Naga (1967). However, the second part was filtered through four layers of cheese-cloth. The filtrated portion was used immediately for the measurement of $\mathrm{pH}$ using a digital $\mathrm{pH}$ meter, and ammonia $\mathrm{N}$ concentration according to Conway (1962) method. Few drops of saturated solution of mercuric chloride were added to the filtrate to stop the microbial activity before its storage for analysis, and then the samples were kept frozen at $-20^{\circ} \mathrm{C}$ for determination of total volatile fatty acids (VFAs). The total VFAs acids were measured using the procedures of Warner (1964).

\section{Statistical analysis:}

Statistical analysis was done according to general linear model (G.L.M) of S.A.S program version 8.2 (2001). Differences among groups for feed intake, milk production, blood parameters, nutrient digestibility and rumen liquor parameters were evaluated by one-way ANOVA. Duncan Multiple Range Test (Steel and Torrie, 1980) was used to test the effect of treatments. The data were presented as mean \pm S.E. Level of significance was set at $\mathrm{P}<0.05$. The statistical model was as follows.

$Y_{i j}=\mu+T_{i}+e_{i j}$

Where: $Y_{i j}=$ the observation $i j, \mu=$ the overall mean, $\mathrm{T}_{\mathrm{i}}=$ the effect due to treatment i., $\mathrm{e}_{\mathrm{ij}}=$ the experimental error.

\section{RESULTS AND DISCUSSION}

\section{Feed intake:}

The results in Table (2) indicate that the daily DM intake from wheat straw and total DM intake by ewes fed rations supplemented with 1.5 and $3 \%$ sodium bicarbonate were significantly $(\mathrm{P}<0.05)$ higher than the intake by control group. The roughage intake was higher $(\mathrm{P}<0.05)$ in group with $3 \%$ sodium bicarbonate compared with the group with only $1.5 \%$ (257.1 vs. $286 \mathrm{~g})$. It has been reported that the addition of $\mathrm{NaHCO}_{3}$ to high concentrate diets controls acidity and increases the palatability of lamb diets through neutralization of acidity which is responsible for improving feed intake (Jacques et al, 1986). Similarly, Tucker et al. (1991) and Shahzad et al. (2007a) found higher DM intake by buffaloes fed high $\mathrm{NaHCO}_{3}$ due to higher rumen $\mathrm{pH}$ or acid base balance. Sarwar et al. (2007a) reported that the addition of $\mathrm{NaHCO}_{3}$ at a rate of $1.15 \%$ increased the dry matter intake for $27 \%$ by growing lambs and for $29 \%$ by adding $1.5 \%$ $\mathrm{NaHCO}_{3}$ in Nili Ravi buffaloes (Sarwar et al., 2007b). The results of the present study were similar to that reported by Wittayakunet al. (2015) who reported that roughage intake was significantly increased due to $\mathrm{NaHCO}_{3}$ supplementation to dairy cow's rations. Furthermore, the addition of sodium bicarbonate to grass silage before feeding lambs increased the dry matter intake from 8 to $20 \%$ (Sormunen et al., 2006). Also, Aguilera-Soto et al. (2008) reported that the supplementation of $\mathrm{NaHCO}_{3}$ to lamb diets increased dry matter intake and feed efficiency. On the other hand, on others studies the voluntary feed intake of the animals was not affected by supplementation of sodium bicarbonate (Mess et al., 1985; and Fellner et al., 2000). Similarly, Santra et al. (2003) found that the daily dry matter intake was not affected by increasing the level of sodium bicarbonate in rations from 0.75 to $2.25 \%$.

Table 2. Effect of sodium bicarbonate supplement to ewe's ration on dry matter intake

\begin{tabular}{|c|c|c|c|c|}
\hline \multirow{2}{*}{ DM Intake (g/day) } & \multicolumn{3}{|c|}{ Treatment } & \multirow{2}{*}{ P-value } \\
\hline & Control & T1 & $\mathbf{T 2}$ & \\
\hline Concentrate & $790.02 \pm 16.02$ & $823.5 \pm 20.22$ & $837.20 \pm 17.84$ & 0.186 \\
\hline Wheat straw & $235.80^{c} \pm 4.47$ & $257.10^{\mathrm{b}} \pm 4.64$ & $286.0^{\mathrm{a}} \pm 5.41$ & 0.001 \\
\hline Total intake & $1026.00^{b} \pm 15.96$ & $1080.60^{\mathrm{a}} \pm 19.57$ & $1123.2^{\mathrm{a}} \pm 20.47$ & 0.004 \\
\hline
\end{tabular}

a,b,c Means of the same row in each item with different superscripts are significantly different $(\mathrm{P}<0.05)$.

T1: ewes received $1.5 \%$ sodium bicarbonate, T2: ewes received $3 \%$ sodium bicarbonate

\section{Milk yield and milk constituents of ewes:}

The average daily milk yield (DMY) of lactating ewes in Table (3) was significantly $(\mathrm{P}<0.05)$ higher in the supplemented sodium bicarbonate groups than in the control group. Also, DMY in T2 which received $3 \%$ of $\mathrm{NaHCO}_{3}$ was significantly $(\mathrm{P}<0.05)$ higher than in $\mathrm{T} 1$ that received $1.5 \%$. Milk fat $(\%)$ was significantly $(\mathrm{P}<0.05)$ increased in the ewes of group fed $3 \%$ of $\mathrm{NaHCO}_{3}$ than in the other groups. However, no significant differences were found among groups for milk constituents, total solid, lactose and protein. The increase of milk yield in ewes fed the diet containing the high rate of $\mathrm{NaHCO}_{3}$ was due to the increased DM intake. Similar results were reported by Tucker et al. (1988) who found that the supplementation of a high level of $\mathrm{NaHCO}_{3}$ improved the milk yield by lactating cows as compared with those fed a low level of $\mathrm{NaHCO}_{3}$. Also, Block (1994) found that high Na or K contents from sodium or potassium bicarbonate increased milk production by lactating cows. The improvement of milk fat in the group fed the high sodium bicarbonate diet may be due to the increase of ruminal $\mathrm{pH}$, which changes the fermentation pattern in a good turn of 
acetate and butyrate production (Kolver and Veth, 2002) and consequently leads to an increase of the $d e$ novo fatty acid synthesis which represented for $60 \%$ of milk fat (Bauman and Davis, 1974) and hence increased milk fat content. $\mathrm{Hu}$ and Murphy (2005) found positive relationships between milk fat and molar proportion of acetate. These findings are supported by Roche et al. (2005) who reported an increased milk fat when sodium bicarbonate was added to the diet. Sarwar et al. (2007b) found a linear increase in milk yield and milk fat \% with increasing sodium bicarbonate levels. Similarly, Wittayakun et al. (2015) found that the daily milk yield was improved by cows supplemented with $\mathrm{NaHCO}_{3}$ and $\mathrm{CaCO}_{3}$. However, the constituents of milk including fat, protein, lactose, solids not fat and total solids were not affected.

Table 3. Effect of sodium bicarbonate supplement to ewe's ration on milk yield (g/day) and its composition $(\%)$

\begin{tabular}{lcccc}
\hline \multirow{2}{*}{ Item } & \multicolumn{3}{c}{ Treatment } & \multirow{2}{*}{ P- value } \\
\cline { 2 - 4 } & Control & T1 & T2 & 0.001 \\
Milk yield & $280^{\mathrm{c}} \pm 8.97$ & $379^{\mathrm{b}} \pm 18.71$ & $489.44^{\mathrm{a}} \pm 13.00$ & 0.716 \\
Total solids & $11.52 \pm 0.22$ & $11.75 \pm 0.21$ & $11.58 \pm 0.19$ & 0.863 \\
Lactose & $6.2 \pm 0.09$ & $6.16 \pm 0.08$ & $6.14 \pm 0.08$ & 0.001 \\
Fat & $6.08^{\mathrm{b}} \pm 0.11$ & $6.28^{\mathrm{b}} \pm 0.08$ & $6.99^{\mathrm{a}} \pm 0.16$ & 0.430 \\
Protein & $4.0 \pm 0.15$ & $4.17 \pm 0.09$ & $4.22 \pm 0.12$ & \\
\hline
\end{tabular}

${ }^{\mathrm{a}, \mathrm{b}, \mathrm{c}}$ Means of the same row in each item with different superscripts are significantly different $(\mathrm{P}<0.05)$.

$\mathrm{T} 1$ : ewes received $1.5 \%$ sodium bicarbonate, $\mathrm{T} 2$ : ewes received $3 \%$ sodium bicarbonate

\section{Blood metabolites:}

The data of serum parameters are summarized in Table (4). The addition of sodium bicarbonate to ewes rations significantly $(\mathrm{P}<0.05)$ increased serum $\mathrm{pH}$ and cholesterol as compared with control group. However, no significant differences were observed among all groups for total proteins, glucose, ALT and AST which indicate no deleterious effect due to $\mathrm{NaHCO}_{3}$ supplement on liver metabolism. Erdman et al. (1982) attributed the changes in blood acid-base status to several factors like secretion of bicarbonate in saliva, abomasal acid secretion, and varied rates of acid utilization and absorption from the rumen. The present results agree with those of Sarwaret al. (2007a) who found a significant increase in blood $\mathrm{pH}$ and serum bicarbonate with increasing $\mathrm{NaHCO}_{3}$ levels of the diet and attributed this to the gradual increase of sodium intake. Leanna (2002) found that the blood protein was not affected by diet or freechoice options of sodium bicarbonate.

Table 4. Effect of sodium bicarbonate supplement to ewe's ration on some blood parameters

\begin{tabular}{lcccc}
\hline \multirow{2}{*}{ Item } & \multicolumn{4}{c}{ Treatment } \\
\cline { 2 - 5 } & Control & T1 & T2 & \\
\hline Total protein, g/dl & $6.85 \pm 0.15$ & $7.15 \pm 0.23$ & $7.2 \pm 0.24$ & 0.381 \\
Glucose, mg/dl & $68.11 \pm 1.28$ & $69.5 \pm 0.26$ & $70.09 \pm 1.94$ & 0.581 \\
Cholesterol, mg/dl & $117.3^{\mathrm{b}} \pm 0.63$ & $120.5^{\mathrm{b}} \pm 0.81$ & $134.42^{\mathrm{a}} \pm 3.34$ & 0.001 \\
$\mathrm{pH}$ & $6.41^{\mathrm{b}} \pm 0.11$ & $7.15^{\mathrm{a}} \pm 0.6$ & $7.26^{\mathrm{a}} \pm 0.02$ & 0.001 \\
ALT,U/L & $26.76 \pm 1.25$ & $22.63 \pm 1.11$ & $26.38 \pm 1.58$ & 0.083 \\
AST,U/L & $57.32 \pm 1.59$ & $58.39 \pm 1.11$ & $61.15 \pm 1.73$ & 0.209 \\
\hline
\end{tabular}

$a, b, c$ Means of the same row in each item with different superscripts are significantly different $(\mathrm{P}<0.05)$.

T1: ewes received $1.5 \%$ sodium bicarbonate, T2: ewes received $3 \%$ sodium bicarbonate

\section{Digestibility:}

The effects of supplemented sodium bicarbonate on nutrients digestibility are shown in Table (5). The organic matter, crude protein and crude fiber digestibility coefficients were improved $(\mathrm{P}<0.05)$ for rams supplemented with 1.5 and $3 \%$ sodium bicarbonate compared with the control group. Likewise, dietary supplement of $3 \% \mathrm{NaHCO}_{3}$ had a significant $(\mathrm{P}<0.05)$ effect on the digestibility of $\mathrm{DM}$ and $\mathrm{EE}$ by rams as compared with those fed the diet supplemented with $1.5 \% \mathrm{NaHCO}_{3}$ or the diet with no supplement (control group). The improvement in nutrients digestibility with sodium bicarbonate supplement to ram's ration may be due to the increase of the total number of ciliate protozoa as well as cellulolytic bacteria (Koul et al., 1998 and Santra et $a l ., 2003)$. This would have contributed to better fiber (cellulose) digestibility in the rumen. Santra et al. (2003) observed that the number of total protozoa was higher $(\mathrm{P}<0.01)$ in the rumen of groups fed rations with high level of sodium bicarbonate $(2.25$ and $1.5 \%$ ) than that fed rations with a lower level $(0.75 \%)$ of $\mathrm{NaHCO}_{3}$. These results are supported by the results of Santra et al. (2003) who found that the digestibility of organic matter, crude protein and gross energy were not affected with increasing the level of sodium bicarbonate in rations. However, Phillip (1983) reported that the digestibility of organic matter and DM was unaffected by the inclusion of $\mathrm{NaHCO}_{3}$ at a rate of $3 \%$ of the diet DM, but digestibility of nitrogen tended to increase due to treatment. 
Table 5. Effect of sodium bicarbonate supplement to ram's ration on nutrient digestibility, \%

\begin{tabular}{|c|c|c|c|c|}
\hline \multirow{2}{*}{ Item } & \multicolumn{3}{|c|}{ Treatment } & \multirow{2}{*}{ P-value } \\
\hline & Control & T1 & $\mathrm{T} 2$ & \\
\hline Dry matter, DM & $75.6^{\mathrm{b}} \pm 0.58$ & $76.44^{\mathrm{b}} \pm 0.47$ & $78.85^{\mathrm{a}} \pm 0.64$ & 0.003 \\
\hline Organic matter, OM & $76.3^{\mathrm{b}} \pm 0.57$ & $78.76^{\mathrm{a}} \pm 0.64$ & $79.2^{\mathrm{a}} \pm 0.61$ & 0.009 \\
\hline Crude protein, $\mathrm{CP}$ & $70.5^{\mathrm{b}} \pm 0.87$ & $74.94^{\mathrm{a}} \pm 0.95$ & $76.6^{\mathrm{a}} \pm 0.74$ & 0.005 \\
\hline Ether Extract, EE & $66.11^{\mathrm{b}} \pm 0.39$ & $67.06^{b} \pm 0.79$ & $69.7^{\mathrm{a}} \pm 0.62$ & 0.003 \\
\hline Crude fiber, $\mathrm{CF}$ & $53.6^{\mathrm{b}} \pm 0.89$ & $58.18^{\mathrm{a}} \pm 1.36$ & $60.91^{\mathrm{a}} \pm 1.50$ & 0.003 \\
\hline Nitrogen free extract, NFE & $79.38 \pm 1.17$ & $80.02 \pm 1.07$ & $79.89 \pm 1.68$ & 0.938 \\
\hline
\end{tabular}

$\mathrm{T} 1$ : ewes received $1.5 \%$ sodium bicarbonate, $\mathrm{T} 2$ : ewes received $3 \%$ sodium bicarbonate

\section{Rumen fermentation indices:}

Supplementation of sodium bicarbonate at a level of 1.5 and $3 \%$ of the concentrate diets increased $(\mathrm{P}<0.05)$ ruminal $\mathrm{pH}$ values, concentrations of total VFAs and total protozoa count as compared with the control diet (Table 6). Moreover, the group receiving $3 \% \quad \mathrm{NaHCO}_{3}$ had significantly higher $(\mathrm{P}<0.05)$ ruminal $\mathrm{pH}$ and total VFAsthan that receiving $1.5 \%$ $\mathrm{NaHCO}_{3}$. The concentration of rumen ammonia nitrogen in the present study did not differ among the groups. However, the concentration of rumen ammonia tended to be lower with supplementing $\mathrm{NaHCO}_{3}$ to rations. Erdman (1988) hypothesized that rumen buffering decrease the existence of acidity produced by volatile fatty acids production in rumen and improves systemic acid base status. The same author in a previous study, Erdman et al. (1982) found that supplementing $1 \% \quad \mathrm{NaHCO}_{3}$ increased rumen $\mathrm{pH}$ from 6.13 to 6.43 in early postpartum cows receiving similar diets. The addition of $\mathrm{NaHCO}_{3}$ increases ruminal $\mathrm{pH}$ in lactating cows (Clayton et al., 1999), buffaloes (Koul et al., 1998) and goats (Cetinkaya and Unal, 1992). The supplementation of higher levels of $\mathrm{NaHCO}_{3}$ increases the total VFAs concentration in the rumen of rams as a result of an increased ruminal microbial activity (Santra et al., 2003). The same author also reported that ruminal $\mathrm{pH}$ and total TVFA increased $(\mathrm{P}<0.05)$ with increasing levels of dietary sodium bicarbonate in the diets. While, ammonia nitrogen concentration was decreased $(\mathrm{P}<0.01)$ due to the supplement of sodium bicarbonate to the diet of lambs. Wittayakun et al. (2015) found that supplementation of $\mathrm{NaHCO}_{3}$ had an effect on osmolality and $\mathrm{pH}$ in the rumen. Phillip (1983) found that rumen ammonia concentration tended to decrease with the addition of $\mathrm{NaHCO}_{3}$. Similarly, Harrison and McAllan (1980) reported that sodium bicarbonate improved the efficiency of synthesis of microbial protein from ammonia and reduced the level of rumen ammonia through an increased rate of absorption because of the higher rumen $\mathrm{pH}$ by $\mathrm{NaHCO}_{3}$. The higher total protozoal count in the present study is confirmed by Santra et al. (2003) who observed that the number of total protozoa was higher $(\mathrm{P}<0.01)$ in the rumen of the groups fed rations containing sodium bicarbonate than those fed the control diet. On the other hand, Askar et al. (2011) found that ruminal $\mathrm{pH}$ and ammonia concentration were not affected by dietary sodium bicarbonate $(1.5 \%)$, but the total concentration of volatile fatty acids tended to increase with buffer supplementation.

Table 6. Effect of sodium bicarbonate supplement to ram's ration on rumen parameters

\begin{tabular}{|c|c|c|c|c|}
\hline \multirow{2}{*}{ Item } & \multicolumn{3}{|c|}{ Treatment } & \multirow{2}{*}{ P-value } \\
\hline & Control & $\mathrm{T} 1$ & $\mathrm{~T} 2$ & \\
\hline ? $\mathrm{H}$ & $5.52^{\mathrm{c}} \pm 0.14$ & $6.30^{b} \pm 0.15$ & $6.91^{\mathrm{a}} \pm 0.16$ & 0.001 \\
\hline Ammonia, $\mathrm{mg} / 100 \mathrm{ml}$ & $12.99 \pm 0.04$ & $12.64 \pm 0.75$ & $11.73 \pm 0.50$ & 0.302 \\
\hline TVFA, mmol/100 ml & $7.52^{\mathrm{c}} \pm 0.25$ & $8.68^{\mathrm{b}} \pm 0.28$ & $11.00^{\mathrm{a}} \pm 0.39$ & 0.001 \\
\hline Total protozoa count, $\times 10^{6} / \mathrm{ml}$ & $3.27^{\mathrm{b}} \pm 0.19$ & $4.40^{\mathrm{a}} \pm 0.21$ & $4.69^{\mathrm{a}} \pm 0.17$ & 0.001 \\
\hline
\end{tabular}

a, b,c Means of the same row in each item with different superscripts are significantly different $(\mathrm{P}<0.05)$.

T1: ewes received $1.5 \%$ sodium bicarbonate, $\mathrm{T} 2$ : ewes received $3 \%$ sodium bicarbonate

\section{CONCLUSION}

It is concluded that sodium bicarbonate supplement in concentrate diet of ewes improve dry matter intake, milk yield and milk fat (\%). Also, addition of sodium bicarbonate to rams rations modifies rumen fermentation and improve nutrients digestibility.

\section{REFERENCES}

Abou El-Naga M., 1967. Some metabolic studies on rumen microorganisms. M.Sc. Thesis, Fac. of Agric., Univ. of Alexandria, Egypt. 
Aguilera-Soto J. I., R.G. Ramirez, C.F. Arechiga, F. Mendez-Llorente, M.A. Lopez-Carlos, J.M. Silva-Ramos, R.M. Rincon-Delgado and F.M. Duran-Roldan, 2008. Effect of feed additives in growing lambs fed diets containing wet brewers grains. Asian-Aust. J. Anim. Sci., 21(10), 14251434.

AOAC, 2005. Official Methods of Analysis (16th ed.). Washington, DC: Association of Official Analytical Chemists, USA.

Ashmawy, B. M, 1980. Comparison of three techniques for the estimation of the milk production of small ruminants. Egyptian .J. Anim. Prod., 20, 11-19.

Askar A.R., J.A. Guada, J.M. González, de Vega and A. C. Castrillo, 2011. Effects of sodium bicarbonate on diet selection and rumen digestion by growing lambs individually fed whole barley grain and a protein supplement at their choice. Anim. Feed Scie. and Technol., 164 (1-20), 4552.

Bauman D. E. and C. L. Davis, 1974. Biosynthes is of milk fat. Pages 31-75 in Lactation: A Comprehensive Treatise, Vol. 2 (Ed. B. L. Larson and V. R. Smith). Academic Press, New York.

Block E, 1994. Manipulation of dietary cation-anion difference on nutritionally related production diseases, productivity, and metabolic responses of dairy cows. J. Dairy Sci., 77, 1437-1450.

Bodas R, P. Frutos, F.J. Giraldez, G. Hervas and S. Lopez, 2009. Effect of sodium bicarbonate supplementation on feed intake, digestibility, digesta kinetics, and nitrogen balance and ruminal fermentation in young fattening lambs. Span J Agric Res., 7, 330-341.

Cetinkaya N., and S. Unal, 1992. Effects of bicarbonate on rumen degradability of concentrate and grass hay in Angora goats. Small Rum. Res., 9, 117-123.

Clayton E.H., I.J. Lean, J.B. Rowe and J.W. Cox, 1999. Effects of feeding virginiamycin and sodium bicarbonate to grazing lactating dairy cows. J. Dairy Sci. 82, 1545-1554.

Conway EJ., 1962. Microdefusion Analysis and Volumetric Error. (5 $5^{\text {th. }}$ Ed.) Crosby- Lockwood and Sons Ltd., London.

Donald L. B., E.B. Shirl, G. Nyles, B. H. William, and J. D. Edward, 1984. Sodiumbicarbonate buffer in dairy cow rations. California Agriculture.

Erdman R. A., 1988. Dietary buffering requirements of lactating dairy cow: a review. J. Dairy Sci., 71, 3246.

Erdman R. A., R. W. Hemken, and L. S. Bull, 1982. Dietary sodium bicarbonate and magnesium oxide for early postpartum lactating dairy cows: Effects on production, acid-base metabolism, and digestion. J. Dairy Sci., 65, 712-731

Fellner V., L. E. Phillip and H. Garino, 2000. Evaluation of the potential protein sparing effects of sodium bicarbonate when added to grass silage for growing steers. Can. J. Anim. Sci., 80, 131136.

Gonzalez LA, A. Ferret, X. Manteca, S. Calsamiglia, 2008. Increasing sodium bicarbonate level in high-concentrate diets for heifers I. Effects on intake, water consumption and ruminal fermentation. Animal, 2, 705-712.

Harris on D. G. and A. B. McAllan, 1980. Factors affecting microbial growth yields in the reticulorumen. Pages 205-226 In Y.

$\mathrm{Hu}$ W. and M. R. Murphy, 2005. Statistical evaluation of early and mid-lactation dairy cow responses to dietary sodium bicarbonate addition. Anim. Feed Sci. Technol., 119, 43-54.

Hutjens M. F., 1991. Feed Additives. Vet. Clinics North Am. Food Anim. Pract., 7, 525-535.

Jacques K. A., D.E Axe, T.R. Harris, D.L. Harmon, K. K. Bolsen and D. E. Johnson, 1986. Effect of sodium bicarbonate and sodium bentonite on digestion, solid and liquid flow, and ruminal fermentation characteristics of forage sorghum silage based diets fed to steers. J. Anim. Sci., 63, 923-932.

Kawas J. R., R. García-Castillo, F. Garza-Cazares, H. Fimbres- Durazo, E. Olivares-Sáenz, G. Hernández-Vidaml and C. D. Lu, 2007. Effects of sodium bicarbonate and yeast on nutrient intake, digestibility, and ruminal fermentation of lightweight lambs fed finishing diets. Small Rumin. Res., 67, 149-156.

Kolver E. S. and M. J. Veth, 2002. Prediction of ruminal $\mathrm{pH}$ from pasture-based diets. J. Dairy Sci., 85, 1255-1266.

Koul V., U. Kumar, V.K Sareen, and S. Singh, 1998. Effect of sodium bicarbonate supplementation on ruminal microbial populations and metabolism in buffalo calves. Ind. J. Anim. Sci, 68, 629-631.

Le Ruyet, P. and W. B. Tucker, 1992. Ruminal buffers: temporal effects on buffering capacity and $\mathrm{pH}$ of ruminal fluid from cows fed a high concentrate diet. J. of Dairy Sci., 75 (4), 10691077.

Leanna E. W., 2002. Offering sodium bentonite and sodium bicarbonate free choice to lactating dairy cattle.M.Sc.,Virginia Polytechnic Institute and State University

Linda G., E. James, and W. James, 1985. Effect of supplementing equivalent cation amounts from nacl, mgo, nahco and caco on nutrient utilization and acid-base status of growing dorset lambs fed high concentrate diets. J Anim. Sci., 60, 307-315.

Mess, D.C., N. R. Merchen, and C.J. Mitchel, 1985. Effect of sodium bicarbonate on nitrogen balance, bacterial protein synthesis and sites of nutrient digestion in sheep. J. Anim. Sci., 61, 985-994.

N.R.C., 1985. Nutrient Requirements of sheep. National Academy of Science. National Research Council, Washington, DC, U.S.A.

NRC. 1989. Nutrient Requirements of Dairy Cattle. 6th revised ed., National Academy Press, Washington D.C. 
Phillip L. E. 1983. Effect of sodium bicarbonate on nitrogen utilization and feed intake by lambs. Can. J. Anim. Sci., 63, 613-62 1.

Roche J. R., S. Petch and J. L. Kay, 2005. Manipulating the dietary cation anion difference via drenching to early lactating dairy cows grazing pasture. J. Dairy Sci., 88, 264-276.

Russell J. B. and J. M. Chow, 1993. Another theory for the action of ruminal buffer salts: Decreased starch fermentation and propionate production, J. of Dairy Sci, 76, 826-830.

SAS., 2001. SAS/ STAT Guide for personal computer (version 8.2 End). SAS. INST., Cary, N.C.

Santra A., O. H. Chaturvedi, M. K. Tripathi, R. Kumar and S. A. Karim, 2003. Effect of dietary sodium bicarbonate supplementation on fermentation characteristics and ciliate protozoal population in rumen of lambs. Small Rumin. Res., 47, 203-212.

Sarwar M. A., M. Shahzad and M. Nisa, 2007a. Nutrient intake, acid base status and growth performance of Thalli lambs fed varying level of dietary cation-anion difference. Asian-Aust. J. Anim. Sci., 20, 1713-1720.

Sarwar M.A, M. Shahzad and M. Nisa, 2007b. Influence of varying level of sodium bicarbonate on milk yield and its composition in early lactating Nili Ravi buffaloes. Asian-Aust. J. Anim. Sci., 20, 1858-1864.

Sen AR, Santra A and S.A Karim, 2006. Effect of dietary sodium bicarbonate supplementation on carcass and meat quality of high concentrate fed lambs. Small Ruminant Res., 65, 122-127.

Shahzad M. A., M. Sarwar and M. Nisa, 2007. Nutrient intake, acid base status and growth performance of growing buffalo male calves fed varying level of dietary cation anion difference. Livest. Sci., 111, 136-143.

Sormunen, C., P. Nykanen-Kurki and L. Jauhiainen, 2006. Effect of partial neutralization of grass silage on feed intake by lambs. In: Sustainable Grassland-Productivity: Proceedings of the $21^{\text {st }}$ General Meeting of the European Grassland Federation, Badajoz, Spain., pp. 532-534.

Steel R.G. and J.H. Torrie, 1980. "Principles and Procedures of Statistics" A Biometrical Approach (2 nd Ed) Mc Grow- Hill Book Co., New York.

Tucker W. B., B. Z. Xin and R. W. Henken, 1991. Influence of calcium chloride on systemic acidbase status and calcium metabolism in dairy heifers. J. Dairy Sci., 74, 1401.

Tucker W. B., J. K. Harris on and R. W. Hemken, 1988. Influence of dietary cation-anion balance on milk, blood urine, and rumen fluid in lactating dairy cattle. J. Dairy Sci., 71, 346.

Warner, A.C.I., 1964. Production of volatile fatty acids in the rumen: methods of measurement. Nutrition Abstract Review, 34, 339.

Wittayakun S., S. Innaree, W. Innaree and W. Chainetr, 2015.Supplement of sodium bicarbonate, calcium carbonate and rice straw in lactating dairy cows fed pineapple peel as main roughage. Slovak J. Anim. Sci, 48 (2), 71-78.



